\title{
Readmission costs related to intensive care after cardiac surgery. analysis of risk factors and costs within six months after discharge using an administrative registry
}

\author{
A Rossi Zadra ${ }^{1 *}$, E Caruso $^{2,3}$ \\ From ESICM LIVES 2015 \\ Berlin, Germany. 3-7 October 2015
}

\section{Introduction}

Prolonged stay in intensive care unit (ICU) after cardiac surgery may increase the long-term risk of readmission. Preoperative risk factors, surgical complications, infections and organ failure may need specific intensive support, increasing costs of reimbursement mainly for ICU interventions. Readmission costs over months after discharge may be a dependant of the need of intensive care.

\section{Objectives}

We analyzed the impact of ICU interventions and patients' conditions on readmission risk and on global costs of reimbursement from the National health service with DRG methodology and assessed the impact of ICU on global costs for complicated cardiac surgery patients.

Table 1 IMPACT OF ADMISSION CONDITIONS.

\begin{tabular}{|c|c|c|c|c|c|c|}
\hline & \multirow{2}{*}{$\begin{array}{l}\text { Risk of readmission (logistic } \\
\text { regression) } \\
\text { estimate (logit) }\end{array}$} & \multicolumn{5}{|c|}{ Impact on global costs (linear regression) } \\
\hline & & $\begin{array}{l}\text { Standard } \\
\text { Error }\end{array}$ & $p$ value & $\begin{array}{l}\text { estimate } \\
\text { (EUR) }\end{array}$ & $\begin{array}{l}\text { Standard } \\
\text { Error }\end{array}$ & $\mathrm{p}$ value \\
\hline Intercept & $-2,416$ & 0,35 & $\begin{array}{l}< \\
0.0001\end{array}$ & 19990 & 1161 & $\begin{array}{l}< \\
0.0001\end{array}$ \\
\hline Female gender & $-0,164$ & 0,11 & 0,14 & -79 & 395 & 0,84 \\
\hline Age (per single year) & 0,009 & 0,005 & 0,06 & -48 & 17 & 0,004 \\
\hline \multicolumn{7}{|c|}{$\begin{array}{l}\text { Lenght of stay (days) base reference 0-15 } \\
\text { days }\end{array}$} \\
\hline $15-28$ & 0,48 & 0,12 & $\begin{array}{l}< \\
0.0001\end{array}$ & 2170 & 459 & $\begin{array}{l}< \\
0.0001\end{array}$ \\
\hline $29-60$ & 0,63 & 0,20 & 0,002 & 5017 & 789 & $\begin{array}{c}< \\
0.0001 \\
\end{array}$ \\
\hline$>60$ & 1,1 & 0,41 & 0.007 & 16464 & 1644 & $\begin{array}{c}< \\
0.0001\end{array}$ \\
\hline Rehab program & 0,46 & 0,13 & 0,0005 & 1036 & 449 & 0,021 \\
\hline
\end{tabular}

${ }^{1} \mathrm{AO}$ Città della Salute e della Scienza, Dipartimento di Anestesia e

Rianimazione, Torino, Italy

Full list of author information is available at the end of the article 
Table 2 IMPACT OF ICU PROCEDURES.

\begin{tabular}{|c|c|c|c|c|c|c|}
\hline & \multirow{2}{*}{$\begin{array}{l}\text { Risk of readmission (logistic } \\
\text { regression) } \\
\text { estimate (logit) }\end{array}$} & \multicolumn{5}{|c|}{ Impact on global costs (linear regression) } \\
\hline & & $\begin{array}{l}\text { Standard } \\
\text { error }\end{array}$ & $\begin{array}{l}\mathrm{p} \\
\text { value }\end{array}$ & $\begin{array}{l}\text { estimate } \\
\text { (EUR) }\end{array}$ & $\begin{array}{l}\text { Standard } \\
\text { error }\end{array}$ & $\mathrm{p}$ value \\
\hline Tracheostomy & 0,41 & 0,379 & 0,28 & 24367 & 1472 & $\begin{array}{c}< \\
0.0001\end{array}$ \\
\hline Shock (any causes) & $-0,44$ & 0,401 & 0,27 & 3030 & 1344 & 0,02 \\
\hline IABP or ECMO & 0,23 & 0,301 & 0,44 & 3318 & 1117 & 0,003 \\
\hline $\begin{array}{l}\text { Mechanical ventilation }>96 \\
\text { hours }\end{array}$ & $-0,48$ & 0,340 & 0,16 & 2158 & 1253 & 0,08 \\
\hline Dialysis & 0,015 & 0,358 & 0,97 & -433 & 1374 & 0,75 \\
\hline
\end{tabular}

Table 3 IMPACT OF OTHER CLINICAL CONDITIONS.

\begin{tabular}{lllllll}
\hline & Risk of readmission (logistic regression) & Impact on global costs (linear regression) & \\
\hline & estimate (logit) & Standard error & $\mathbf{p}$ value & estimate (EUR) & Standard error & $\mathbf{p}$ value \\
\hline Infection & 0,331 & 0,322 & 0,30 & -265 & 1235 & 0,83 \\
\hline Blood transfusion & 1,06 & 0,321 & 0,0009 & -2847 & 1292 & 0,03 \\
\hline Diabetes & 0,34 & 0,164 & 0,04 & -1033 & 616 & 0,09 \\
\hline Heart failure & 0,34 & 0,124 & 0,006 & 1319 & 459 & 0,004 \\
\hline Recent myocardial ischemia & $-0,131$ & 0,130 & 0,32 & -1817 & 460 & $<0.0001$ \\
\hline Respiratory disease & 0,062 & 0,188 & 0,74 & -634 & 698 & 0,36 \\
\hline Kidney disease & 0,440 & 0,202 & 0,03 & -484 & & 788 \\
\hline Peripheral vascular disease & 0,247 & 0,124 & 0,05 & -1086 & 454 & \\
\hline
\end{tabular}

\section{Methods}

We selected 2067 patients who were admitted to ICUs after cardiac surgery in Regione Piemonte, Italy, in 2009 and analyzed all administrative data listing diagnosis and procedures according to ICD-9CM definitions. Known risk factors for complications and surgical events were selected as ICD-9CM codes. Specific ICU procedures were included if they had impact in DRG calculation. Hospital history was followed for six months after discharge and costs of new admissions were related to selected codes and conditions at the first intervention. We used hazard models and regression analysis to identify ICD9-CM codes that are predictors of readmission and their impact on reimbursement costs, with regard to ICU events.

\section{Results}

528 out of $2067(25,54 \%)$ patients had in total 877 readmissions. In this population hospital length of stay, tracheostomy, heart or kidney failure, infection and the use of IABP or ECMO are strong risk factors for readmission. Tracheostomy accounts for the major increase of costs as DRG consider it an indicator for extensive use of ICU resources. Shock and prolonged mechanical ventilation are inversely related to increased risk of readmission, but they require additional significant expenditure. Some negative findings on the risk of readmission may be explained with increased mortality rate in those patients. Full results are shown in Tables 1-3.

\section{Conclusions}

The need of ICU stay and procedures after cardiac surgery may significantly increase the risk of readmission and of reimbursement fee. The ICD-9CM coding system for administrative purposes might be a reliable indicator for the actual clinical risk described in existing literature and predict an increase of expenditure. Health systems should consider ICU costs in allocating resources for cardiac surgery.

\section{Authors' details}

${ }^{1}$ AO Città della Salute e della Scienza, Dipartimento di Anestesia e Rianimazione, Torino, Italy. ${ }^{2}$ Università di Perugia, Perugia, Italy. ${ }^{3}$ CAPP, Modena, Italy.

Published: 1 October 2015

\section{References}

1. Brewer $\mathrm{R}$, et al: Morbidity but not mortality is decreased after off-pump coronary artery bypass surgery. Ann Thorac Surg 2014, 97(3):831, Mar.

2. Price $J D$, et al: Risk analysis for readmission after coronary artery bypass surgery: developing a strategy to reduce readmissions. J Am Coll Surg 2013, 216(3):412-9, Mar. 
3. Hannan EL, et al: 30-day readmissions after coronary artery bypass graft surgery in New York State. JACC Cardiovasc Interv 2011, 4(5):569-76, May.

doi:10.1186/2197-425X-3-S1-A65

Cite this article as: Rossi Zadra and Caruso: Readmission costs related to intensive care after cardiac surgery. analysis of risk factors and

costs within six months after discharge using an administrative registry. Intensive Care Medicine Experimental 2015 3(Suppl 1):A65.

Submit your manuscript to a SpringerOpen ${ }^{\mathcal{O}}$ journal and benefit from:

- Convenient online submission

- Rigorous peer review

- Immediate publication on acceptance

- Open access: articles freely available online

- High visibility within the field

- Retaining the copyright to your article

Submit your next manuscript at $\gg$ springeropen.com 